the gradual rise and fall of the river was almost regular, day by day, the maximum flow occurring about 9 a.m. and the minimum about 9 p.m., the difference between the two amounting to nearly Io per cent. of the total quantity passing down the river at the time of minimum flow. Various suggestions as to the cause of this phenomenon have been made, but I am unable to give any satisfactory explanation. It occurs in winter as well as in summer, and may take place daily throughout the year, though it cannot be observed except during dry periods. It may well be that a similar phenomenon occurs in other rivers, but has escaped observation owing to the absence of recording gauges.

\section{THE INTERNATIONAL GEOLOGICAL} CONGRESS.

THE ninth gathering of the International Geological Congress was held this year in Vienna. After a preliminary series of excursions through different parts of Austria-Hungary the members assembled in the rooms of the University on Thursday, August 20, when the meeting was inaugurated by the Archduke Rainer and the Minister of Public Instruction. According to the programme prepared by the committee of organisation, each alternate day was to be devoted to the reading and discussion of papers on given subjects of general interest, while the intervening days were given up to excursions in the neighbourhood of the imperial city. After the formal opening of the congress, the afternoon of the first day was spent, under the presidency of $\mathrm{Mr}$. Emmons, of the United States Geological Survey, in receiving a miscellaneous group of communications, including a paper on the Laccolites of the Aar-massif by Prof. Baltzer. and an account of the recent volcanic eruptions of Martinique and St. Vincent by Mr. E. O. Hovey, illustrated by an excellent series of photographic lantern slides. The next day of discussion (August 22) was dedicated to the crystalline schists, under the chairmanship of Prof. Zirkel in the morning and Prof. Loewinson-Lessing in the afternoon. Until the various communications are in print and can be studied and compared, it is hardly possible to say how far they have advanced our knowledge of the subject. The speakers on this and subsequently on the other selected subjects of discussion showed a prevailing tendency to dwell on the local peculiarities of the regions most familiar to them, and rather to lose sight of the general principles to which local observations should properly lead. The crystalline schists of Germany, Austria, the Alps, Finland and North America were all brought into review, so that a sufficiently wide basis was provided for satisfactory generalisation. The third day (August 24) for the reading of papers, under the presidency of Sir Archibald Geikie in the furenoon and Prof. Heim in the afternoon, was spent in listening to essays by various geologists on the important phenomena embraced under the general designation of "overthrusts." MM. Lugeon and Haug described the structures displayed in the Alps, Prof. Uhlig those of the Carpathians, Mr. Bailey Willis thuse of the United States. In an interesting discussion Prof. Heim indicated that he surrendered the so-called "doublefold " of the Glärnish, as originally advocated by him, and now admitted that the structure implied a gigantic overthrust. Prof. Rothpletz, who has long maintained this view, also took part in the debate, which at times became lively from the energy of the speakers and the difficulty which they found in confining their exuberance within the limits of time prescribed by the council. Though the ductrine of overthrusts was admitted, considerable divergence of opinion appeared as to the true nature and origin of the structure.

Wednesday (August 26) was dedicated to a consideration of the geology of the Balkan peninsula and the East, under the presidency of Prof. Barrois in the forenoon and Prof. Tschernyschew in the afternoon. An interesting and important series of papers was read, in which the present state of our knowledge of these regions was detailed by those geologists to whom the recent advance of that knowledge has mainly been due.

On Thursday (August 27) the morning was taken up in the reception of miscellaneous communications in four different rooms of the University. As this extensive building includes a large number of rooms separated from each other by staircases and passages, and as no adequate system of placards was adopted to guide the members to these various meetingplaces, much time was lost in trying to find them, and in some instances the search was abandoned in despair. The afternoon was devoted first to the reception of the reports of the various Commissions appointed by the congress at previous meetings. A satisfactory statement was made by Prof. Beyschlag as to the progress of the international geolugical map of Europe. Sir Archibald Geikie gave in the report of the Commission on lines of raised beach in the northern hemisphere and also that of the Commission on international cooperation in geological research. On his proposal it was agreed to form a small committee for the purpose of collecting infurmation from different countries with a view to combined effort in those branches of inquiry which are not purely geological but require the services of other sciences. The first number of the "Palæontologia Universalis" was laid before the meeting by M. Oehlert, who was warmly congratulated on the successful launching of this enterprise. The report of the Commission on glaciers was presented by M. Finsterwalder. The recommendation of the committee appointed to consider the Spendiaroff prize was unanimously adopted, that the prize should be awarded to Prof. Brögger, of Christiania. The last official act of the congress was to choose the next place of meeting, which, by a majority, was fixed to be Mexico.

A very unpleasant impression was made on a number of members of the congress by the action of the Vienna committee of organisation in regard to the next meeting place. So far back as March last the general secretary wrote to Dr. Bell, acting director of the Geological Survey of Canada asking whether an invitation could be sent from Canada to hold the next meeting of congress there, and assuring him that many Austrian geologists would be very pleased to visit that country and would be happy to support the invitation at the approaching Vienna meeting. No mention was made in that letter, or in any subsequent comniunication, that applications had been sent to any other country. Dr. Bell replied in the same month of March that he cordially welcomed the proposal and would do all in his power to further its acceptance. The Geological Survey and the Royal Society of Canada warmly supported it, and eventually the Government authorities took it up and Parliament actually voted 25,000 dollars towards the necessary expenses of the meeting. Dr. Bell was commissioned tu proceed to Vienna and personally invite the congress to hold their next session in Canada. On arriving in Vienna, however, he found that, unknown to any one in Canada, the committee had also been simultaneously in treaty with Mexico, and without writing to know what was being done in Canada had inserted in the official programme an invitation which had in response been received from Mexico. He soon saw that though the committee could not bind the congress, they had practically decided the question in favour of Mexico so far as their votes and influence could go. The Canadian authorities naturally feel indignant at such treatment, and it will excite no surprise if they are in no hurry to renew their invitation should the visit to Mexico fail of accomplishment.

Excursions have always formed a prominent part of the work of the geological congress, and this year they have been organised on a greater scale than ever before. Not only was there a diversified series set on foot before the meeting and another after it, but half the time of the congress in Vienna was devoted to excursions in the neighbourhood. Whether these miscellaneous parties contribute as much as might be desired to the enlargement of the geological experience and knowledge of the congressists, they at least have une excellent result inasmuch as they bring together scientific friends who have seldom a chance of meeting eacn other and, likewise, enable them to make the personal acquaintance of men with whose writings they may have been long familiar. Indeed, it may be asserted that the fostering of such personal acquaintance is perhaps the most practically valuable part of the work of the congress. For the enlightenment of the excursionists an admirable Livret Guide to Austrian geology was drawn up by Dr. Teller. Of this publication an account will be given in another issue of NATURE.

No. I 769 , VOL. 68] 